\title{
Strategic human resource management and corporate social responsibility: Evidence from Emerging Markets
}

\author{
Talita Rosolen ${ }^{1}$ and Maria Laura Ferranty Maclennan \\ University of São Paulo - USP, São Paulo, SP, Brazil.
}

\section{ARTICLE DETAILS}

\section{Article history:}

Received 30 September 2015

Accepted 4 April 2016

Available online in 30 August 2016

Double Blind Review System

\section{Scientific Editor}

Eduardo Eugênio Spers

\section{Keywords:}

Strategic human resource management

Corporate social responsibility

Ethics

Environment

Emerging markets.

\begin{abstract}
Corporate social responsibility practices are increasingly being adopted and legitimized in business and they impact the strategic and operational levels in various areas. The integration of these criteria and practices in the strategic management involves many factors, and human resource management is an essential aspect for the accomplishment of such initiative. Thus, this paper associates the relationship among corporate social responsibility (CSR) various dimensions (strategic, ethical, social and environmental) and strategic human resource management (SHRM) in companies operating in Brazil. We also aim to identify whether there is impact of other aspects on this relationship, namely: size, industry and company internationalization level (if national or multinational). Results show evidence that ethical CSR can be associated to SHRM. Environmental CSR showed marginal relation, and social and strategic CSR presented no significant association. Those results emphasize the need to further develop strategic actions of CSR into human resource management in emerging markets. Managers can also benefit from those findings, as it is possible to have a broad view of limitations and opportunities regarding the role played by human resource management in CSR.
\end{abstract}

(C) 2016 Internext | ESPM. All rights reserved!

\section{Introduction}

Corporate social responsibility (CSR) becomes part of strategic planning of many organizations, and is broadly spread through policies and practices involving its various stakeholders, specially their own workforce (Sharma \& Henriques, 2005). This subject is especially relevant in international business because as companies enter new markets, they operate in contexts and environments they are not fully adapted to (Daher, 2006). Companies have taken the environmental and social dimension more seriously and incorporated those principles into their business strategy and daily operations (Dolci, Lunardi, Salles, \& Alves, 2015). In this context, CSR integration into human resource strategies may generate competitive advantage to the firm.

From the 1980s, human resources begin to be perceived as strategic assets for organizations, with competitiveness growth in the business environment and the differentiation among intellectual capital and the company's knowledge management (Legge, 2005). So, this public becomes more important in the strategic agenda of organizations, seeking to develop people management practices aligned to organizational goals, here called strategic human resource management (SHRM) (Beer, Boselie, \& Brewster, 2015, Lepak \& Shaw, 2008, Wright \& McMahan, 1992).

Among the challenges posed by the rise of competitiveness and globalization to the SHRM, we can highlight the significance of CSR (Fischer \& Albuquerque, 2005, Vickers, 2005). The balance among social, environmental and economic values can only be achieved by a company through its workforce involvement; hence human resource department is often part of the CSR strategy. Some studies emerge relating both concepts due to their influence to the general business strategy, but the

\footnotetext{
${ }^{1}$ Corresponding author: Email: rosolen@usp.br
} 
field needs further theoretical developments. International studies show a deeper advancement with qualitative as well as quantitative research. Brazilian publications, on the other hand, are focused on an exploratory and qualitative approach of the relationship between CSR and SHRM, which emphasizes the need for more quantitative studies to consolidate the knowledge in this field (Parente \& Fischer, 2014).

From the importance that CSR and SHRM pose to organizational objectives, this study investigated the relationship between the advancement of these aspects and practices in companies' management. Additionally, this study will examine the effect of intervening factors such as size, industry (manufacturing or trade and services) and internationalization (if national or multinational).

Pressures towards the adherence of organizations to CSR's principles are primarily related to an approach that boosts value generation on an ongoing basis (Porter \& Kramer, 2006). CSR concept in literature is broad and involves several aspects related to organizational management. Those are strategies, policies and practices connected to the different stakeholders with whom the company relates, such as customers, employees, suppliers, government agencies, media, etc. However, in order to SHRM assume a proactive conduct towards CSR, it is important to split the later concept into four dimensions: strategic, ethics, social, and environmental.

SHRM is relevant not only as one of the actors that demand responsible behavior from organization, but also as a group who can engage and disseminate actions and values aimed at a socially responsible enterprise culture (Beer et al., 2015, Vickers, 2005). This study contribution to literature associates SHRM practices with CSR. This is a relevant theme of study taking into account the Brazilian context, as CSR practices are not well developed in emerging market (Campbell, Eden, \& Miller, 2012; Govindan, Kannan, \& Shankar, 2014). We identified a gap in the study of SHRM, as it is not clear how CSR strategies can be disseminated into the workforce and what are the most frequent initiatives undertaken by human resource management.

Besides, we can point out the need to understand how CSR practices are adopted by SHRM management from companies in an emerging economy such as Brazil. Those are at an early stage in the development of CSR, because institutional pressures are not as strong as in traditional ones (Kothari, Kotabe, \& Murphy, 2013). Therefore, our study contributes to literature linking SHRM with the main directions of CSR adoption in Brazilian companies. As a managerial contribution, our study highlights the most and least institutionalized dimensions of CSR adoption by human resource managers. This can lead to a more proactive role of human resource management towards CSR in emerging markets context.

\section{Corporate social responsibility}

The discussions about the concept of sustainable development began to acquire great visibility in the late 1980s, with the report Our Common Future, also known as the Brundtland Report, produced by the World Commission on Environment and Development (WCED) (Brundtland, 1991). A diagnosis about global environmental problems proposed that economic growth may be integrated with the environmental issue. This new development model, which implies a balance between economic, social and environmental aspects, has become widespread in government, business and civil society level. According to Barbieri, Vasconcelos, Andreassi, and Vasconcelos (2010), awareness on the theme became larger to the extent that social organizations and the public sector started to pressure businesses to consider their externalities and their role as citizens towards society as a whole. So CSR and corporate citizenship begun to integrate corporate agenda, initially focused in philanthropy, specific actions and short-term results.

Also, publications on the subject begun to appear in universities and organizations (Fischer, 2002), indicating a growing awareness movement, generation of knowledge and transparency, which would result in the internalization of these concepts into organizational culture. Some companies feared that concern about this subject would add more costs than benefits and persuaded them to take on social responsibilities that are responsibility of governments and individuals, since there was no consistency in the concept.

Social and environmental innovations developed by companies, often in partnership with civil society organizations, show not only internal benefits, but also towards larger issues of society. Stands out, then, the creation of shared value, which according to 
Porter and Kramer (2006) generates advantages to companies while seeking to achieve social well-being through business mechanisms.

The concept of CSR is wide and can be approached by different angles. CSR is here defined as integrated strategic, ethical, social, and environmental concerns, on a voluntary basis, in business operations and in companies' interaction with their stakeholders (Barin Cruz \& Boehe, 2008). CSR practices are shown in literature associated to social issues as volunteering and philanthropy (Daher, 2006; Porter \& Kramer, 2006), pollution prevention and reduction of environmental impact (González-Benito \& GonzálezBenito, 2006; Orsato, 2006), publication of sustainability reports (Kolk \& Van Tulder, 2010), accountability, transparence and governance policies (Augustine, 2012; Haniffa \& Cooke, 2002), economic responsiveness (Carroll, 1998) among other actions towards ethical corporate behavior.

It is important to point out that CSR is understood as a broad concept, which can gather initiatives that are too different from each other. Hence, the relevance of analyzing the construct divided in dimensions that better explain the strategic movements adopted by companies. Therefore, we split the concept into four dimensions: (i) strategic, (ii) ethic, (iii) social, and (iv) environment.

\subsection{Strategic CSR}

One aspect that drives companies towards more socially responsible management is to gain a competitive advantage over competition. Savitz and Weber (2007) propose that the social and environmental aspects should be considered to the extent that the company is influenced by them and therefore requires a more systemic approach. Thus, convergence is sought with broader interests involving business functions from the production process to the functional areas around a larger goal. By linking social and environmental aspects of the company with competitive advantages also demonstrates the intersection with business strategy (Porter \& Kramer, 2006; Porter \& Van der Linde, 1995). Studies in this direction tend to seek to relate the adoption of CSR practices with greater returns on investment to explain the strategic bond (Knoepfel, 2001).

With the advancement of the discussions around the theme, companies start to realize benefits in adopting responsible practices through competitive advantage range as its competitors. To modify its processes and products to meet the legal demands and civil society, the company will develop innovations that provide financial opportunities and competitiveness (Porter \& Van der Linde, 1995). CSR then reaches a strategic level in organizations as it contributes to the achievement of its strategic objectives.

Business strategy encompasses aspects relevant for the achievement of the company's CSR results as a whole. Strategic CSR involves: (i) the establishment of strategic goals and actions towards sustainability in the long term, (ii) products and processes that comply with international patterns, (iii) the adoption of environmental certifications and commitment to norms and standards that may vary among regions of operation, as well as (iv) the disclosure of sustainability reports (Augustine, 2012; Chakrabarty \& Wang, 2012; Daher, 2006; Dolci et al., 2015).

\subsection{Ethics in CSR}

Faria and Sauerbronn (2008) highlight the need of management tools to maximize ethical and moral performance in organizations, aimed to achieve competitive advantage. In the long run, it is beneficial to society and also for companies to make clear that what is worthy for the company may be also beneficial for society (Pereira \& Campos Filho, 2007).

Carroll (1979), who promoted the discussion about CSR, suggests that "business social responsibility encompasses the economic expectations, legal, ethical and discretionary that society has of the organization at a given point of time" (Carroll, 1979, p. 500). In a review of this initial model, Schwartz and Carroll (2003) argue that decisions are driven strongly by economic and ethical aspects, namely strategic for the development of the discretionary aspects (environmental issues).

It is noteworthy that there is no consensus about the nature of the ethical dimension and who would be responsible for this dimension. The discussion was initially divided between those who defend stockholders view (Friedman, 2007), where the only social responsibility of the company's management is to increase the return on capital invested by the shareholders. There are also those who believe in stakeholders view (Freeman, 2010), in which management should concealment the various stakeholders - customers, consumers, suppliers, 
employees, community, since all are impacted by organization's decisions.

According to Christensen, Peirce, Hartman, Hoffman, and Carrier (2007), the ethical approach to CSR seeks to emphasize the business objectives in an effort to turn ethics into a manageable variable. Such perspective ensures that ethical issues are not diluted in the administrative proceedings and ignored in the daily lives of companies. So, codes of conduct, missions, beliefs and principles are created in order to guide business activities at all hierarchical levels (Helin \& Babri, 2015; Kreitlon, 2012). This highlights the importance of managing people to consider ethical aspects in CSR and develop their influential role in spreading this culture. Savitz and Weber (2007) propose the importance of this more responsible way of doing business in employees' decisions, both in routine operations and in strategic decisions.

\subsection{Social dimension of CSR}

Social issues are part of the corporate agenda, initially through philanthropy and short-term actions. However, the advanced pace of expansionary process of the business sector drew attention to the consequent intensification of the impacts caused by large corporations operations. Fischer (2002) argues that there is an awareness generation movement towards increased knowledge and transparency, involving both companies and domestic public and other publics that boosted the internalization of CSR into organizations culture.

It is possible to observe some business leaders pro-activity seeking to bring changes in corporate posture by promoting practices that reflect commitment to social and environmental aspects, besides strictly economic. The social dimension regards concern for social and human welfare, related to education, health, job creation, equity and fair labor relations, non-discrimination, and ethical values (Dyllick \& Hockerts, 2002; Slaper \& Hall, 2011).

Thus, companies have begun to develop social actions with stakeholders involvement, which potentially bring benefits not only to the image in relation to external audiences, but can also generate shared value with employees and their families, community, production chain, and with customers or other parts that are impacted by the organization (Porter \& Kramer, 2006). Companies with poor social performance, assessed by their own metrics, ethical and legal requirements, risk themselves of economic and trade sanctions, and may be excluded from the market if somehow their actions generate negative impacts to their communities where they operate. If they operate in a socially irresponsible manner not complying with its labor obligations, or making use of child labor or forced labor, forced or degrading sanctions may apply.

\subsection{Environmental dimension of CSR}

The influences for the adherence of the CSR practices organizations are mainly linked to the need for an approach to generate uninterrupted value, ensuring the long-term success and aligning their processes and strategies for the integration of three objectives that must go in line: economic growth, environmental protection and social equity. Bansal and Roth (2000) identify three reasons for the adoption of environmental practices strategies: competitiveness, legitimacy and ecological responsibility. From these reasons, it is clear that organizational sustainability consolidates the adoption of environmental preservation practices combined with profitability and business competitiveness.

The environmental dimension of sustainability is linked to the rational use of available natural resources. The main objective is to reduce the impact of productive activities on the ecosystem through the development of more efficient processes, material waste reduction and prevention of environmental incidents (Costantini \& Mazzanti, 2012). Bazerman and Hoffman (1999) suggest four reasons for the adoption of sustainability by companies: (i) as a category of excellence in trying to achieve technological innovation, (ii) the involvement of businesses in the formulation of rules and regulations by the government, (iii) the ability of companies to influence the adoption of environmental and social standards, and the development of solutions in this area, and (iv) the arising business benefits of adopting innovations related to products that meet environmental demands. Those reasons combine CSR with environmental protection. In order to merge CSR into business strategy, it is necessary to consider changes not only in political and in the company's speech, but also should be disseminated in the operation, influencing aspects of organizational culture and getting a clear need for employee engagement at this time.

Those dimensions are explained in Table 1: 
Tab. 1

CSR Dimensions

\begin{tabular}{lll}
\hline Dimension & Definition & Authors \\
\hline Strategic CSR & $\begin{array}{l}\text { Strategies should consider stakeholders value and align CSR actions } \\
\text { and measures in organizations to achieve competitive advantage. }\end{array}$ & $\begin{array}{l}\text { Porter and Kramer (2006); Porter } \\
\text { and Van der Linde (1995); Savitz and } \\
\text { Weber (2007) }\end{array}$ \\
\hline Ethics in CSR & $\begin{array}{l}\text { Business objectives comprise an effort to turn ethics into a Christensen et al. (2007); Helin and } \\
\text { manageable variable, through the establishment of corporate ethical } \\
\text { principles and codes of conduct. }\end{array}$ & $\begin{array}{l}\text { Babri (2015); Savitz and Weber } \\
\text { (2007); Schwartz and Carroll (2003) }\end{array}$ \\
\hline $\begin{array}{l}\text { Social dimension } \\
\text { of CSR }\end{array}$ & $\begin{array}{l}\text { Regards concern for social and human welfare, related to education, } \\
\text { health, job creation, equity and fair labor relations, non- } \\
\text { discrimination, and ethical values, involving the whole community. }\end{array}$ & $\begin{array}{l}\text { Dyllick and Hockerts (2002); Fischer } \\
\text { (2002); Slaper and Hall (2011) }\end{array}$ \\
\hline $\begin{array}{l}\text { Environmental } \\
\text { dimension of CSR }\end{array}$ & $\begin{array}{l}\text { This dimension consolidates the adoption and measurement of } \\
\text { environmental preservation practices combined with profitability } \\
\text { and business competitiveness. }\end{array}$ & $\begin{array}{l}\text { Bansal and Roth (2000); Bazerman } \\
\text { and Hazzanti (2012) }\end{array}$ \\
\hline
\end{tabular}

Source: The authors

Other literature that integrates several concepts into CSR is the triple bottom line (TBL). The concept of TBL also boosted the adoption of environmentally responsible practices as it approached the relationship between the prospects of sustainable development and corporate objectives. This approach challenges the view that companies should only worry about its financial performance and suggests that the business strategy should cover the triple analysis results: economic results, environmental performance and added social outcomes or destroyed in the wealth creation process short, medium and long term (Elkington, 1994, 1999). Thus, it reached the goal of meeting the needs of today's society and of future generations, supporting the concept of sustainable development.

Pires and Fischer (2014) propose an internal coherence between the RSC and SHRM towards organization's strategy. In this sense, SHRM can play vital role to induce changes in workforce behavior to achieve successful adoption of such strategic direction.

\section{International human resource management and corporate social responsibility}

Regarding multinational companies management, HRM is a relevant topic to achieve global performance. International Human Resource Management (IHRM) has become a source of competitive advantage due to a world driven by capabilities and knowledge (Brewster, Sparrow, Vernon, \& Houldsworth, 2011). Dowling, Festing, \& Engle (2008, p.5) define IHRM as "all issues related to the management of people in an international context". Given this definition, is important to associate IHRM to global CSR strategy.

In this sense, some authors suggest that the search for legitimacy in acting in different countries where a multinational installs its subsidiaries is an important factor and can encourage adherence to practices that increase local commitment, such as CSR (Campbell et al., 2012). It is stablished that integrated human resource systems have a positive impact on performance over individual practices among the multinational company (Boxall \& Macky, 2009).

However, the dilemma of determining global strategies and practices at the expense of local needs adaptation can indicate different ways for this to occur. It is proposed, therefore, that there is a balance between actions that are determined globally and locally, it is important to establish broad strategies that should be applied in all countries of operation in order to maintain unity and corporate identity, but also the opening for the development of molded practices to local realities and needs (Muller, 2006).

Human resource managers pursue to conciliate institutional pressures from local regulations and actors with corporate practices (Rupidara \& McGraw, 2011). SHRM plays a role on that through the adaptation of policies and procedures from headquarters to subsidiaries, as well as preserving its cultural identity. In this sense, it is important to consider the context in which the firm operates, as it may impact the firm's strategy, operations, and its functional areas (Schuler, Budhwar, \& Florkowski, 2002). 
Mayrhofer, Brewster, Morley, and Ledolter (2011) address the question of human resources practical settings in different countries and question whether there is convergence or divergence in people management in different regions. They argue that there is a propensity of convergence of these practices, since there is commitment to developing unified institutional structures, but the particularities of each country may hinder the adoption of similar practices. Thus, indicate the propensity of a directional similarity occur, so that strategy and practice have a common goal, but with adjustments to each situation.

Tanure (2005) presents integration on global and local aspects. She states that corporate values should be common among different business unities, however, policies and practices towards the workforce should consider local characteristics and company's peculiarities. In the same direction, Brewster (2007) advocates adapting people management practices to the organizational context and the region in which the company operates in detriment of universal practices that could be applied to any context.

This trend is even stronger if considered emerging markets competitive environment (Govindan et al., 2014). Emerging markets are characterized by having deficiencies in infrastructure, institutions and market agents (Khanna, Palepu, \& Bullock, 2010), and they have to cope with market deficiencies as corruption, business informality and security and educational gaps (Banerjee, Prabhu, \& Chandy, 2015; CuervoCazurra, Holan, \& Sanz, 2014; Torres, Alfinito, Galvão, \& Tsé, 2015). It is important to note that in those markets they are not homogeneous; however, all of them have those issues in some degree (Ramamurti, 2012).

Academic research linking the influence of human resource practices to the achievement of strategic corporate results are scarce in our context and do not reflect the Brazilian reality as a whole. According to Tanure, Evans, and Cançado (2010), in many Brazilian companies the human resources department is focused on operational and bureaucratic activities. They fail to demonstrate the benefits of a strategic interaction to the organization. On the other hand, the appreciation of models and practices already consolidated in other countries could reinforce the adoption of a more strategic human resource management and influence a more active role of the area in the company.

In order to help, SHRM can contribute to the international company to gain legitimacy not only from stakeholders in the country of origin, but as well as those located in the destination country (Daher, 2006). The search for legitimacy in their internal operations can be regarded as an important factor that relates the adoption of CSR in multinational companies, and human resource management can take a leading role on that. The establishment of environmental departments and appointment of sustainability managers can indicate that top management places special meaning to the issue (González-Benito \& González-Benito, 2006). The emergence of those departments might be aligned with a SHRM.

\section{Strategic human resource management and hipotesis development}

The economic and society development is based on knowledge and in the discovery of new technology has brought strong impacts on organizational models. The process of globalization and the rapid spread of information even over long distances caused the global business expansion and increased complexity of the flow of information and decisions in companies (Evans \& Wurster, 2000). This global and competitive environment spurred the search for a more strategic role of human resource management, as firms make a shift towards strategic mindset (Rupidara \& McGraw, 2011).

In this scenario, human resources are now considered an important asset for companies that need more and more of their intellectual capital to raise their ability to compete with the others (Legge, 2005). The strategic role that people management in organizations can take begun to be discussed academically from the 1980s. Initially treated as personnel department and regarded with only operational functions, human resources area had to adapt its activities to meet the strategic demands in order to achieve better results for companies.

These discussions emerged two main approaches in human resource management: Harvard Model (Beer, Spector, Lawrence, Mills, \& Walton, 1984) and the Michigan Model (Fombrun, Tichy, \& Devanna, 1984), which propose a long-term orientation and better internal adjustment assembly practices (horizontal alignment) and about company's strategy 
(vertical alignment). The Harvard model emphasized a social systems perspective, considering stakeholders' interests and a long-term contribution to society, whilst the Michigan Model was more focused on an individual perspective pursuing enhancement of performance and the maximization of shareholders' earnings (Beer et al., 1984; Fombrun et al., 1984; Beer et al., 2015).

Wright and McMahan (1992) present a more comprehensive theoretical approach about the strategic management of human resources, involving the integration of activities of different functions of the area in order to achieve strategic aims of the organization. It is important for the human resources leader to be involved on strategic formulation, participate in strategic committee and in the implementation of those strategies.

According to Vickers (2005), human resources should play an active role in cultivating a socially responsible environment in the company mostly through four responsibilities: (i) helping to keep it as a top priority by business leaders; (ii) including this component in leadership selection and development systems; (iii) ensuring the right programs and policies are being adopted and respected throughout the company; and (iv) taking part in ethical and social responsibility issues.

Based on these approaches, it is possible to emphasize the importance that a more strategic human resource management can have in CSR strategies adoption. It is important to highlight that corporate culture Strategies that contemplate stakeholder's value, take full advantage of ethical and moral performance in organizations searching for competitive advantage. This can be achieved by setting CSR goals and actions, patterns, certifications and the disclosure of reports. From those developments, we state the first hypothesis:

\section{$\mathrm{H1}$ : Strategic human resource leads to strategic CSR actions.}

Human resource management system shall comprise a set of policies and practices in order to drive employee behavior toward organizational strategic objectives. Lepak and Shaw (2008) emphasize the importance of the system as a whole rather than the analysis of individual practices, especially if they do not represent consistency when considered together. Corporate ethics codes are adopted in the hope to ensure sustainable actions acceptance through the company (Kreitlon, 2012). Human resources may take an active role on organizational culture, training employees to comply with ethical procedures and code of conduct (Vickers, 2005). These statements lead to the second hypothesis:

\section{$\mathrm{H} 2$ : Strategic human resource leads to ethic CSR actions.}

In spite of employee well-being being subject of several studies, its impact on the environment and society have largely been neglected by academic studies and hence not considered essential for the strategic management of human resources. Beer et al. (2015) point out that study in human resources did not follow the expansion of the corporate vision for a multi-stakeholder approach, and maintained a more reductionist vision guided by economic bias. In this sense, concerns about welfare, community and social issues should be considered in SHRM. From those, we propose the third hypothesis:

\section{H3: Strategic human resource leads to social CSR actions.}

Environmental strategies are increasingly seen as a potential source of competitive and strategic advantage (Orsato, 2006). Managerial attitudes towards environmental concerns have a positive effect on the adoption of a proactive environmental strategy.

Proactive environmental strategies can be considered a systematic set of voluntary practices that go beyond regulatory requirements to improve the environmental performance and manifested through different strategies. They include the establishment of environmental policies, environmental standards for suppliers, environmental auditing, reduction of costs and environmental disclosure reports with environmental information published to the general public (Sangle, 2010; Walker, Ni, \& Huo, 2014). This can only be achieved with the involvement of the whole organization. In that sense, SHRM play an important role by disseminating corporate values, training and linking sustainability with personal performance goals. From that, the fourth hypothesis is:

\section{$\mathrm{H} 4$ : Strategic human resource leads to environmental CSR actions.}

Based on the above, we outline our model of how SHRM may influence the various CSR dimensions. It is shown in Figure 1: 


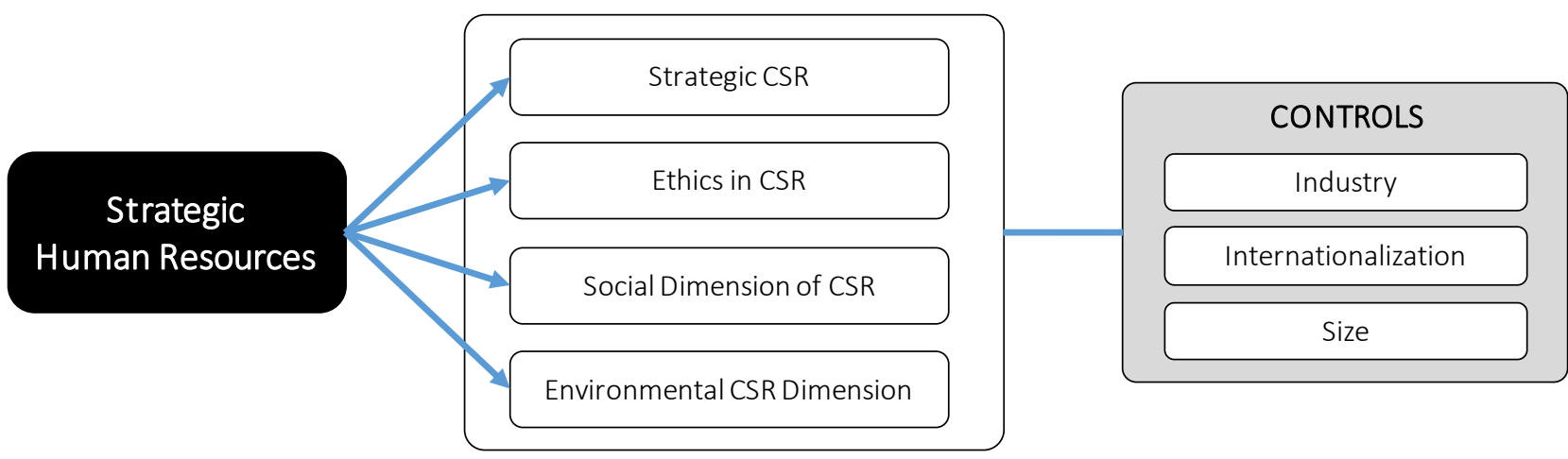

Fig. 1

Theoretical model

Source: The authors.

\section{Research design}

The methodological design that guided this research is based on quantitative approach. The process of data collection relied upon secondary data of the Best Companies to Work For, 2014 edition, published by Guia Voce S/A. This is an annual survey run by FIA Business School since 2006 with companies that operate in Brazil. We used the 287 companies' responses for the 2014 edition regarding issues that address aspects of CSR and aspects of SHRM and characterization of the database (number of employees, national or multinational and the industry it operates). Table 2 shows the data profile of the sample.

Tab.2

Sample profile

\begin{tabular}{ccc}
\hline $\begin{array}{c}\text { Company Size } \\
\text { \# of employees }\end{array}$ & Number of Companies & $\%$ \\
\hline Up to 250 & 32 & $11 \%$ \\
from 251 to 500 & 64 & $22 \%$ \\
from 500 to 1000 & 46 & $16 \%$ \\
from 1001 to 2500 & 63 & $22 \%$ \\
over 2500 & 82 & $29 \%$ \\
\hline Industry & Number of Companies & $\%$ \\
\hline Services & 138 & $48 \%$ \\
Manufacturing & 125 & $44 \%$ \\
Retail & 24 & $8 \%$ \\
\hline Internationalization & Number of Companies & $\%$ \\
\hline Local & 205 & $71 \%$ \\
Multinational & 82 & $29 \%$ \\
\hline
\end{tabular}

Source: authors

In order to analyze the data profile, we used descriptive statistics. Data in Table 1 shows that service and manufacturing industry prevails in the sample over retail (92\%), and those local companies also are more representative (71\%). Regarding size, most companies are considered large, as the number of employees excels 2500 people (29\%).

\subsection{Construction of the research variables}

The questionnaire surveys a broader set of variables, so we selected the ones in the interest of the study: SHRM and CSR. In this study, the dependent variable is the adoption of a SHRM (Wright \& van de Voorde, 2009; Wright \& McMahan, 1992). It was built based on the scores by summing the answers to the variables about the formal definition of HR strategic guidelines, participation of managers in HR decisions and the involvement of human resources with the development of business strategy. Note that these dimensions, which participated in the composition of the dependent variable, are also the dimensions supported by the literature. Therefore, we assign credibility and robustness to the overall rate of SHRM created by the authors. Cronbach's alpha for this variable is 0.69 .

As independent variables, the study used the concepts of CSR split in four dimensions: strategic, ethic, social and environmental, as explained in Figure 1. Following the same procedures above and aligned to previews research (Pavan, Parente, Rosolen, Borini, \& Oliveira Jr, 2013), we constructed a variable for each dimension, considering the sum of answers given by the respondents.

Strategic CSR considers if sustainability is regarded as part of business strategy, measuring leadership involvement, processes and structure, suppliers selection towards sustainability, targets definition, auditing and metrics towards sustainability, and 
reports (Porter \& Kramer, 2006; Porter \& Van der Linde, 1995; Savitz \& Weber, 2007)). Cronbach's alpha for this variable is 0.79 .

Ethics CSR evaluates if the company has developed and disseminated a code of conduct to guide the behavior of its employees, trained teams for ethical behavior and followed accounting disclosure guidance (Helin \& Babri, 2015; Kreitlon, 2012; Savitz \& Weber, 2007). This variable had a Cronbach's Alpha of 0.69 .

The social dimension of CSR measures if the organization developed social actions in the last year, by the adoption of formal or informal mechanisms for evaluating programs and social actions involving their employees (Beer et al., 2015; Sharp \& Zaidman, 2010). Cronbach's alpha for this variable is 0.72 .

Finally, the environmental dimension comprises organized activities for the preservation of the environment (Bansal \& Roth, 2000; González-Benito \& González-Benito, 2006). Cronbach's alpha for this variable is 0.71 .

Stand out, also, other elements that may explain the responsible performance of a company: size, industry and internationalization. In this sense, there is the reputational aspect. It is evident that the larger companies are driven to develop a leading role in CSR issues, as environmental proactivity, mainly because of its visibility and magnitude of the impacts that generates (González-Benito \& González-Benito, 2006; Johnston \& Menguc, 2007). Those are more pressured by society and tend to adopt CSR strategies to keep a positive corporate image. In this direction, companies from emerging markets may adopt CSR strategies in order to mitigate disadvantages in their late internationalization process and need to catch up on technology and best practices (Barin Cruz, Boehe, \& Ogasavara, 2015).

From this development, the following variables were controlled for the study: the first control variable is the level of internationalization, controlled in a dummy variable ( 1 for multinational and 0 for local companies). Also, the study controlled for industry ( 1 for manufacturing or 0 for trade and services) and size.

\section{Results}

From the sample of 287 companies available in the database, the industry those firms operate were classified into two major groups: (i) manufacturing sector (44\%), and (ii) companies providing services and trade (56\%). Regarding internationalization, it was observed that multinationals account for $29 \%$ of the database, and local companies for $71 \%$. Size is explained in Table 2, as are the other variables. Size uses the number of employees as a proxy.

The first phase of the study sought to verify the assumptions of normality and collinearity between groups. Normality test called Kolmogorov - Smirnov showed that the variables had significant asymmetry between the two tails, at levels below 0.001 . Therefore, one can consider data distribution as normal (Hair, Black, Babin, Anderson, \& Tatham, 2009). Table 3 shows Pearson correlations. Independent variables correlations are low when significant, and it fulfills one of the assumptions of the regression, which is the absence of strong correlation ( $p>0.7$ ) between variables (Hair et al., 2009).

In order to investigate the relationship between SHRM and CSR, we performed a three-stage regression. Model 1 shows the relationship among

Tab. 3

Pearson correlation

\begin{tabular}{|c|c|c|c|c|c|c|c|c|c|}
\hline & Variables & 1 & 2 & 3 & 4 & 5 & 6 & 7 & 8 \\
\hline 1 & SRH & 1 & & & & & & & \\
\hline 2 & Strategic CSR &, $317^{* *}$ & 1 & & & & & & \\
\hline 3 & Ethical CSR &, $388 * *$ &, $532 * *$ & 1 & & & & & \\
\hline 4 & Social CSR &, $208^{* *}$ &, $558 * *$ &, $459 * *$ & 1 & & & & \\
\hline 5 & Environmental CSR &, $314 * *$ &, $661 * *$ &, $481 * *$ &, $566 * *$ & 1 & & & \\
\hline 6 & Internationalization level &, $180 * *$ &, $224 * *$ & $215^{* *}$ & $138^{*}$ & ,138* & 1 & & \\
\hline 7 & Size & 047 &, $137^{*}$ &, $192 * *$ &, $193 * *$ & ,119* & ,085 & 1 & \\
\hline 8 & Industry &,- 078 &,$- 188 * *$ &,- 024 & ,015 &,$- 165 * *$ &,$- 222 * *$ &, 064 & 1 \\
\hline
\end{tabular}

** Correlation is significant at the 0.01 level (2-tailered)

* Correlation is significant at the 0.05 level (2-tailered)

Source: The authors 
control variables and SHRM. The second model (model 2) tests CSR constructs without controls, and the third model tests the complete model.

In Table 4 is possible to see the lack of multicollinearity, seen through the VIF test with results that are lower than 5 (Maroco, 2003). Therefore, the regression confirms hypothesis $\mathrm{H} 2$ and marginally confirms $\mathrm{H} 4$. It also rejects $\mathrm{H} 1$ and $\mathrm{H} 3$. So, it is possible to stablish that strategic human resource management indicates actions towards ethic CSR. Comparing models 2 and 3 , it is possible to see that the complete model has a more robust explain power.

Tab.4

Regression model

\begin{tabular}{lcccc}
\hline \multicolumn{1}{c}{ Variables } & Model 1 & Model 2 & Model 3 & VIF \\
\hline Constant & 2,231 & 1,330 & 1,301 & \\
CSR Strategic & $-x-$ & 0,095 & 0,08 & 2,14 \\
CSR Ethical & $-x-$ &, $281^{*}$ & $0,273^{*}$ & 1,54 \\
CSR Social & $-x-$ & $-0,62$ & $-0,058$ & 1,69 \\
CSR Environmental & $-x-$ & $-0,133$ &, $137^{* *}$ & 2,02 \\
\hline Level of & & & & \\
Internationalization & $-0,111$ & $-x-$ &,- 033 & 1,07 \\
Size & 0,0001 & $-x-$ &, 000 & 1,06 \\
& & & & \\
Industry & 0,522 & $-x-$ &, 264 & 1,12 \\
\hline F & 5,001 & 15,245 & $9,128^{*}$ & \\
$R^{2}$ adjusted & 0,034 & 0,178 & 0,186 & \\
\hline
\end{tabular}

Source: The authors

It is possible to stablish that the greater adoption of strategic human resource initiatives and practices, more proactive the company is oriented towards conduct codes that lead to ethical behavior. It is likely to state, from the results that strategic human resource management is marginally relevant to environmental CSR actions. Control variables adopted in this study - internationalization, size and industry - showed no significant association in the model.

\section{Discussion}

Results indicate that the integration of ethics on business behavior is part of the role of SHRM agenda. The positive association between SHRM and CSR ethics highlights the importance of corporate efforts applied by human resource management, as discussed by Beer et al. (2015), Christensen et al. (2007), and Vickers (2005). Many firms have implemented formal programs in order to promote ethical management behavior and to foster legal compliance. From those results it is notable how SHRM has taken an active role in spreading ethical practices in Brazilian organizations. As Brazilian business environment is often associated with corruption, informality and illegal practices (Banerjee et al., 2015; Torres et al., 2015), it is plausible to assume that SHRM is committed with efforts to spread ethical values and behavior within the company.

Another outcome of the analyses is that environmental CSR has a positive and marginal association with SHRM. That can be explained by the importance of involving the entire organization towards the adoption of rational use of natural resources due to the rapid depletion of the environment. Given the growing pressure from regulatory agencies, society and consumers for ecofriendly operations, companies are developing several environmental initiatives, dedicating time and resources from every department. SHRM can take an active role by influencing the adoption of social and environmental standards. This can be achieved by engaging employees with training activities and corporate dynamics developed to stimulate the development of environmental innovation.

According to the results, there was no significance in the relation between SHRM and social dimension of CSR. This can be attributed to the prevalence of volunteering and philanthropic initiatives that are not necessarily related to strategic corporate programs. Social programs organized by corporations that beneficiate communities are still at an early stage. Punctual initiatives and the shortage of performance measurements in social aspects may explain the lack of this association, in managers' perception. Some Brazilian companies have developed more robust social projects and foundations in areas, such as education, health and income generation for poor communities. However, they still lack long-term commitment, which could be a contribution of SHRM in this dimension.

Surprisingly, we found no significant association between the strategic dimension of CSR and SHRM. This may indicate that SHRM is still more involved with tactical and daily-bases activities, as pointed out by Tanure (2005), rather than leading strategical movements, as the disclosure of sustainability reports, green supply chain initiatives and integrating sustainability values into corporate strategy. We 
suggest that future research address this relationship in different sets of samples in order to verify possible associations and better understand it.

Control variables showed no association to the model. Size was unexpected, because literature explains that bigger companies may have mode incentives from stakeholders and resources to invest in CSR initiatives (Campbell et al., 2012). The internationalization level also showed no association. This may imply that local stakeholders and institutional pressures may be more relevant to this matter than human resource policies, practices and knowledge imported from headquarters (CuervoCazurra et al., 2014). In this sense, local and multinational CSR may be resultant of institutional pressures and a response to local stakeholders' demands, as local adaptation played a significant role in CRS adaptation to local context (Muller, 2006). Also, we found no significant relation with the industry of operation. This can be a theme for further investigation.

\section{Conclusions}

Our study sought to investigate the relationship between SHRM and CSR dimensions. Specifically, we analyzed the influence of SHRM in strategic, ethical, social and environmental CSR actions. In addition, we examined the effects of intervening factors such as internationalization, size and industry. The relevance of this study relies on association of the strategic human resource management with the advancement of corporate social responsibility, especially in the context of a developing country.

Although there are studies that investigate the relationship between these constructs, they do not specify how SHRM influences the different dimensions of CSR. In this manner, our research verified that SHRM do not influence CSR dimensions in the same way. SHRM acts more proactively in ethical and environmental dimensions and is less present in social and strategic CSR.

We found evidence of a positive association between SHRM and CSR ethics, which indicates the importance of the involvement of the human resources department in the dissemination of values and behaviors aligned with ethical conducts. Results also showed a positive and marginal association of SHRM and environmental CSR. We can infer that human resources policies and practices help motivate employees to engage and commit to environmental practices towards a sustainable future. On the other hand, we found no significance in the relation between SHRM and social and strategical dimensions of CSR, as well as no association among the control variables.

Additionally, we point out the contribution to the literature of SHRM and CSR in an emerging market, which is still at an earlier stage of development of these practices. We emphasize the importance of a more proactive role of SHRM in adopting and disseminating CSR practices in the emerging markets context, and that the integration of these concepts may generate competitive advantage to the firm, as suggested by Beer et al., 2015 and Vickers, 2005.Some limitations from the study are a consequence of the secondary database collection methodology. As the respondents were participating in a survey focused on being one of the Best Companies to Work for, this may express a bias on the answers. The findings are generalizable for the Brazilian context, and it is necessary further research to verify if is replicable in other emerging or developed markets.

For future studies, we suggest that a qualitative approach could bring further explanations to these results and to the relationship between SHRM and CSR. This could involve aspects as corporate training and volunteering, among other CSR topics. Also, it is important to verify the reasons why the ethical and environmental dimensions of CSR overcome strategic and social ones. Correlated studies may apply. Furthermore, the motives why multinationals do not show more advanced SHRM may be an interesting topic for future research.

\section{References}

- Augustine, D. (2012). Good Practice in Corporate Governance: Transparency, Trust and Performance in the Microfinance Industry. Business Society, 659(51), 659-676.

- Banerjee, S., Prabhu, J. C., \& Chandy, R. K. (2015). Indirect Learning: How Emerging-Market Firms Grow in Developed Markets. Journal of Marketing, 79(1), 10-28.

- Bansal, P., \& Roth, K. (2000). Why companies go green: a model of ecological responsiveness. Academy of Management Journal, 43(4), 717-736.

- Barbieri, J. C., Vasconcelos, I. F. G., Andreassi, T., \& Vasconcelos, F. C. (2010). Inovação e sustentabilidade: novos modelos e proposições. 
RAE-Revista de Administração de Empresas, 50(2), 146-154. DOI: http://dx.doi.org/10.1590/S003475902010000200002

- Barin Cruz, L., \& Boehe, D. M. (2008). CSR in the global marketplace: Towards sustainable global value chains. Management Decisions, 46(8), 1187 1209.

- Barin Cruz, L., Boehe, D. M., \& Ogasavara, M. H. (2015). CSR-based Differentiation Strategy of Export Firms From Developing Countries: An Exploratory Study of the Strategy Tripod. Business \& Society, 54(6), 723-762. DOI: $10.1177 / 0007650312473728$.

- Bazerman, M. H., \& Hoffman, A. J. (1999). Sources of environmentally destructive behavior: Individual, organizational, and institutional perspectives. Research in organizational behavior, 21, 39-79.

- Beer, M., Spector, B., Lawrence, P., Mills, D. Q. \& Walton, R. (1984). Human resource management: A general manager's perspective. New York, NY: Free Press.

- Beer, M., Boselie, P., \& Brewster, C. (2015). Back to the Future: Implications for the Field of HRM of the Multistakeholder Perspective Proposed 30 Years Ago. Human Resource Management, 54(3), $427-$ 438.

- Boxall, P., \& Macky, K. (2009). Research and theory on high-performance work systems: Progressing the high-involvement stream. Human Resource Management, 9(1), 3-23.

- Brewster, C. (2007). Comparative HRM: European views and perspectives. The International Journal of Human Resource Management, 18(5), 769-787. DOI:10.1080/09585190701248182

- Brewster, C., Sparrow, P., Vernon, G., \& Houldsworth, E. (2011). International human resource management. $3^{\text {rd }}$ edition. London: Chartered Institute of Personnel and Development.

- Brundtland, G. H. (1991). Nosso Futuro Comum (Vol. 2). Rio de Janeiro: FGV.

- Campbell, J. T., Eden, L., \& Miller, S. R. (2012). Multinationals and corporate social responsibility in host countries: Does distance matter? Journal of International Business Studies, 43(1), 84-106. DOI: 10.2139/ssrn.1928016

- Carroll, A. B. (1979). A three-dimensional conceptual model of corporate performance. Academy of Management Review, 4(4), 497-505.
- Carroll, A. B. (1998). The Four Faces of Corporate Citizenship. Business and Society Review, 100(1), 117.

- Chakrabarty, S., \& Wang, L. (2012). The long-term sustenance of sustainability practices in MNCs: A dynamic capabilities perspective of the role of $R \& D$ and internationalization. Journal of Business Ethics, 110(2), 205-217.

- Christensen, L. J., Peirce, E., Hartman, L. P., Hoffman, W. M., \& Carrier, J. (2007). Ethics, CSR, and sustainability education in the Financial Times top 50 global business schools: Baseline data and future research directions. Journal of Business Ethics, 73(4), 347-368.

- Costantini, V., \& Mazzanti, M. (2012). On the green and innovative side of trade competitiveness? The impact of environmental policies and innovation on EU exports. Research Policy, 41(1), 132-153. DOI: 10.1016/j.respol.2011.08.004

- Cuervo-Cazurra, A., Holan, P. M. d., \& Sanz, L. (2014). Location advantage: Emergent and guided co-evolutions. Journal of Business Research, 67(1), 508-515. DOI:10.1016/j.jbusres.2013.11.007

- Daher, W. M. (2006). Responsabilidade social corporativa: geração de valor reputacional nas organizações internacionalizadas. São Paulo: Saint Paul Editora.

- Dolci, D. B., Lunardi, G. L., Salles, A. C., \& Alves, A. P. F. (2015). Implementation of Green IT in organizations: a structurational view. Revista de Administração de Empresas, 55(5), 486-497. DOI: 10.1590/S0034-759020150502

- Dowling, P., Festing, M., \& Engle, A.D. (2008). International human resource management: Managing people in a multinational context. (5th ed.) Thomson Learning, London, UK.

- Dyllick, T., \& Hockerts, K. (2002). Beyond the business case for corporate sustainability. Business Strategy and the Environment, 11(2), 130-141.

- Elkington, J. (1994). Towards the Sustainable Corporation: Win-Win-Win Business Strategies for Sustainable Development. California Management Review, 36(2), 90-100.

- Elkington, J. (1999). Cannibal with forks: triple botton line of 21st century business. Oxford: Capstone Publishing Limited.

- Evans, P., \& Wurster, T. (2000). Blow to bits: how the new economics of information transform strategy. Boston: Harvard Business School Press.

- Faria, A., \& Sauerbronn, F. F. (2008). Is corporate social responsibility a strategic issue? A critical 
approach. Revista de Administração Pública, 42(1), 7-33.

- Fischer, R. M. (2002). O desafio da colaboração: práticas de responsabilidade social entre empresas e terceiro setor. São Paulo: Gente.

- Fischer, A. L., \& Albuquerque, L. G. (2005). Trends of the human resources management model in Brazilian companies: a forecast according to opinion leaders from the area. The International Journal of Human Resource Management, 16(7), 1211-1227.

- Fombrun, C. J., Tichy, N. M., \& Devanna, M. A. (1984). Strategic human resource management. New York, NY: Wiley.

- Freeman, R. E. (2010). Strategic management: A stakeholder approach. Cambridge: University Press.

- Friedman, M. (2007). The social responsibility of business is to increase its profits: Springer.

- González-Benito, J., \& González-Benito, Ó. (2006). A review of determinant factors of environmental proactivity. Business Strategy and the Environment, 15(2), 87-102.

- Govindan, K., Kannan, D., \& Shankar, K. M. (2014). Evaluating the drivers of corporate social responsibility in the mining industry with multicriteria approach: A multi-stakeholder perspective. Journal of Cleaner Production, 84, 214-232. DOI: 10.1016/j.jclepro.2013.12.065

- Hair, J. F., Black, W. C., Babin, B. J., Anderson, R. E., \& Tatham, R. L. (2009). Análise Multivariada de Dados (Vol. 6). Porto Alegre: Bookman.

- Haniffa, R. M., \& Cooke, T. (2002). Culture, corporate governance and disclosure in Malaysian corporations. Abacus, 38(3), 317-349.

- Helin, S., \& Babri, M. (2015). Travelling with a code of ethics: a contextual study of a Swedish MNC auditing a Chinese supplier. Journal of Cleaner Production, 107, 41-53. DOI: 10.1016/j.jclepro.2014.08.056

- Johnston, S., \& Menguc, B. (2007). Subsidiary size and the level of subsidiary autonomy in multinational corporations: a quadratic model investigation of Australian subsidiaries. Journal of International Business Studies, 38(5), 787-801. DOI: $10.1057 /$ palgrave.jibs.8400294

- Khanna, T., Palepu, K., \& Bullock, R. (2010). Vencendo em Mercados Emergentes. Harvard Business Review, 88(6), 80-85.
- Knoepfel, I. (2001). Dow Jones Sustainability Group Index: A Global Benchmark for Corporate Sustainability. Corporate Environmental Strategy, 8(1), 6-15. DOI: 10.1016/S1066-7938(00)00089-0

- Kolk, A., \& Van Tulder, R. (2010). International business, corporate social responsibility and sustainable development. International Business Review, 19(2), 119-125.

- Kothari, T., Kotabe, M., \& Murphy, P. (2013). Rules of the Game for Emerging Market Multinational Companies from China and India. Journal of International Management, 19(3), 276-299. DOI: 10.1016/j.intman.2013.03.007

- Kreitlon, M. P. (2012). McMoral, iPolítica, cidadania Wireless: reflexões para o ensino e a pesquisa em RSE no Brasil. Revista de Administração Contemporânea, 16(2), 271-289.

- Legge, K. (2005). Human resources, realities and rethorics: London: Palgrave.

- Lepak, D. P., \& Shaw, J. D. (2008). Strategic HRM in North America: looking to the future. The International Journal of Human Resource Management, 19(8), 1486-1499.

- Maroco, J. (2003). Análise estatística com utilização do SPSS. Lisboa: Edições Sílabo.

- Mayrhofer, W., Brewster, C., Morley, M. J., \& Ledolter, J. (2011). Hearing a different drummer? Convergence of human resource management in Europe - A longitudinal analysis. Human Resource Management Review, 21(1), 50-67.

- Muller, A. (2006). Global versus local CSR strategies. European Management Journal, 24(2), 189-198.

- Orsato, R. J. (2006). When does it pay to be green? California Management Review, 48(2), 128.

- Parente, T. C., \& Fischer, A. L. (2014). A relação entre recursos humanos e sustentabilidade como tema emergente: Uma análise bibliométrica. Revista Alcance, 21(3), 398-421. DOI: 10.14210/alcance.v21n3.p398-421

- Pavan, K. R., Parente, T. C., Rosolen, T., Borini, F. M., \& Oliveira Jr, M. M. (2013). A Responsabilidade Socioambiental das Empresas Estrangeiras no Brasil: Uma Comparação com as Empresas de Capital Nacional. In: 3Es, 2013, Bento Gonçalves, 1-15.

- Pereira, W. A., \& Campos Filho, L. A. N. (2007). Investigação sobre as semelhanças entre os modelos conceituais da responsabilidade social corporativa Revista de Gestão Social e Ambiental, 1(1). DOI: 10.5773/rgsa. v1i1. 12 
- Pires, F. M., \& Fischer, A. L. (2014). Integração entre gestão de pessoas e estratégia de sustentabilidade: o caso Natura. Revista de Gestão Social e Ambiental, 8(1), 54-72.

- Porter, M. E., \& Kramer, M. R. (2006). Strategy \& Society: The Link Between Competitive Advantage and Corporate Social Responsibility. Harvard Business Review, 84(12), 78-92.

- Porter, M. E., \& Van der Linde, C. (1995). Toward a new conception of the environmentcompetitiveness relationship. The journal of economic perspectives, 9(4), 97-118.

- Ramamurti, R. (2012). What is really different about emerging market multinationals? Global Strategy Journal, 2(1), 41-47. DOI: 10.1002/gsj.1025

- Rupidara, N. S., \& McGraw, P. (2011). The role of actors in configuring HR systems within multinational subsidiaries. Human Resource Management Review, 21(3), 174-185. DOI: 10.1016/j.hrmr.2011.02.003

- Sangle, S. (2010). Empirical analysis of determinants of adoption of proactive environmental strategies in India. Business Strategy and the Environment, 19(1), 51-63.

- Savitz, A. W., \& Weber, K. (2007). The sustainability sweet spot. Environmental Quality Management, $17(2), 17-28$.

- Schwartz, M. S., \& Carroll, A. B. (2003). Corporate social responsibility: A three-domain approach. Business Ethics Quarterly, 13(04), 503-530.

- Sharma, S., \& Henriques, I. (2005). Stakeholder influences on sustainability practices in the Canadian forest products industry. Strategic Management Journal, 26(2), 159-180.

- Sharp, Z., \& Zaidman, N. (2010). Strategization of CSR. Journal of Business Ethics, 93(1), 51-71.
- Schuler, R. S., Budhwar, P. S. \& Florkowski, G. W. (2002), International Human Resource Management: Review and Critique. International Journal of Management Reviews, 4 (1), 41-70. DOI: 10.1111/1468-2370.00076

- Slaper, T. F., \& Hall, T. J. (2011). The triple bottom line: what is it and how does it work. Indiana Business Review, 86(1), 4-8.

- Tanure, B. (2005). Gestão à brasileira: somos ou não diferentes?: uma comparação com América Latina, Estados Unidos, Europa e Ásia (2 ed.). São Paulo: Atlas.

- Tanure, B., Evans, P., \& Cançado, V. L. (2010). As quatro faces de $\mathrm{RH}$ : analisando a performance da gestão de recursos humanos em empresas no Brasil. Revista RAC, 14(4), 594-614.

- Torres, C., Alfinito, S., Galvão, C. A. S. P., \& Tsé, B. C. Y. (2015). Brazilian Jeitinho versus Chinese Guanxi: Investigating their Informal Influence on International Business. Revista de Administração Mackenzie, 16(4), 77-99. DOI: 10.1590/167869712015/administracao.v16n4p77-99.

- Vickers, M. R. (2005). Business Ethics and the hr role: past, present, and future. Human Resource Planning, 28(1), 26-32.

- Walker, K., Ni, N., \& Huo, W. (2014). Is the Red Dragon Green? An Examination of the Antecedents and Consequences of Environmental Proactivity in China. Journal of Business Ethics, 125(1), 27-43. DOI: 10.1007/s10551-013-1903-z

- Wright, P., \& van de Voorde, K. (2009). Multilevel issues in IHRM: mean differences, explained variance, and moderated relationships. Handbook of international human resource management: integrating people, process, and context, 29-40.

- Wright, P. M., \& McMahan, G. C. (1992). Theoretical perspectives for strategic human resource management. Journal of Management, 18(2), 295-320.

\section{ABOUT THE AUTHORS}

- Talita Rosolen is Doctoral student and researcher in Business Administration at Universidade de São Paulo-USP E-mail: talita.rosolen@usp.br.

- Maria Laura Ferranty Maclennan is Doctoral student in Business Administration pela Universidade de São Paulo - USP. E-mail: ferranty@hotmail.com. ORCID: 0000-0002-5019-7492 


\title{
Gestão estratégica de recursos humanos e responsabilidade social corporativa: Evidências de mercados emergentes
}

\author{
Talita Rosolen e Maria Laura Ferranty Maclennan
}

Universidade de São Paulo - USP, São Paulo, SP, Brasil.

\section{DETALHES DO ARTIGO}

\section{Histórico do artigo:}

Recebido em 30 de setembro de 2015

Aceito em 4 de abril de 2016

Disponível online em 31 de agosto de 2016

Sistema de Revisão "Double Blind Review"

Editor científico:

Eduardo Eugênio Spers

\section{Palavras-chaves:}

Gestão Estratégica de Recursos Humanos Responsabilidade Social Corporativa Ética

Meio Ambiente

Mercados Emergentes.

\begin{abstract}
RESUMO
Práticas de Responsabilidade Social Corporativa são cada vez mais adotadas e legitimadas nas empresas e passam a impactar a gestão dos níveis estratégicos e operacionais em variadas áreas. A incorporação desses critérios e práticas na gestão estratégica do negócio passa por diversos fatores, sendo a gestão do público interno um aspecto essencial para o sucesso de tal iniciativa. Assim, o presente trabalho propõe verificar a relação entre as diferentes dimensões (estratégica, ética, social e ambiental) da Responsabilidade Social Corporativa (RSC) e a Gestão Estratégica de Recursos Humanos (GERH) em empresas que atuam no Brasil. Pretende-se, ainda, identificar se há impacto de outros aspectos sobre essa relação, quais sejam: tamanho, setor e nível de internacionalização (nacional ou multinacional). Os resultados apontaram evidências de que a dimensão ética da RSC pode ser associada à GERH. A dimensão ambiental da RSC mostrou relação marginal, enquanto as dimensões social e estratégica não apresentaram relação significativa. Esses resultados ressaltam a necessidade de desenvolvimento de ações estratégicas de RSC na gestão de recursos humanos em países emergentes. Gestores também podem se beneficiar dessas descobertas, uma vez que possibilitam uma visão ampliada das limitações e oportunidades acerca do papel desempenhado pela gestão de recursos humanos na RSC.
\end{abstract}

(C) 2016 Internext | ESPM. Todos os direitos reservados!

To cite this article:

Rosolen, T. \& Maclennan, M. L. F. (2016) Strategic human resource management and corporate social responsibility: Evidence from Emerging Markets. Internext - Revista Eletrônica de Negócios Internacionais, 11 (2), p. 66-80.

To link to this article: $h t t p: / / d x . d o i . o r g / 10.18568 / 1980-4865.11266-80$ 